\title{
Captives of Controversy: \\ The Myth of the Neutral Social Researcher in Contemporary Scientific Controversies
}

\author{
Pam Scott \\ Evelleen Richards \\ Brian Martin \\ University of Wollongong
}

\begin{abstract}
According to both traditional positivist approaches and also to the sociology of scientific knowledge, social analysts should not themselves become involved in the controversies they are investigating. But the experiences of the authors in studying contemporary scientific controversies-specifically, over the Australian Animal Health Laboratory, fluoridation, and vitamin $C$ and cancer-show that analysts, whatever their intentions, cannot avoid being drawn into the fray. The field of controversy studies needs to address the implications of this process for both theory and practice.
\end{abstract}

Scientific controversies have long excited both the passions of participants and the interest of social scientists. ${ }^{1}$ For researchers into the nature of science, controversies have the advantage that social processes normally hidden in laboratories and offices are brought into open view in a dramatic fashion. Assumptions that are normally implicit are challenged by disputants, routine procedures scrutinized, and weak points in arguments attacked. The disadvantage of studying controversies is that they may give an unrealistic picture of the day-to-day operations of normal science (Mulkay, Potter, and Yearley 1983). In any case, controversy analysis is a thriving field of study, no doubt due, in part, to their human drama and social implications.

The traditional social science approach to scientific controversies has been to study the social dynamics of science, assuming that there is a scientific truth underlying the debate. Usually one side is believed to be much closer to this core truth, and the task of the social scientist then becomes one of explaining why the other side persists in its claims. The social scientist usually accepts the judgment of the most authoritative scientists about scientific realities. 
This positivist approach, a "sociology of scientific error," has been challenged by relativist analysts of science. In the strong program in the sociology of scientific knowledge, the analyst is enjoined to treat competing truth claims symmetrically (Bloor 1976). Instead of looking only at the side considered wrong by scientific authorities, the knowledge claims on both sides of the controversy are examined, and an attempt is made to explain them using social categories. ${ }^{2}$ The relativist program differs from the traditional approach in two major, related ways. First, the social analysis is applied to scientific knowledge claims, as well as to wider social dynamics. Second, both sides in the controversy are examined using the same repertoire of conceptual tools. This contrasts with the traditional approach, in which scientific knowledge claims are seldom scrutinized (that task is left to the scientists), and social explanations are selectively applied to the side without authoritative scientific backing. It should be noted that relativism is a set of methodological specifications. Relativists may (or may not) believe that there is an underlying scientific truth. But for the purposes of social analysis, they set the issue of truth and falsity aside: it is not treated as relevant to the social investigation.

Under both positivist and relativist approaches, the controversy is normally treated as something external to the researcher. It is "out there": the social research itself is not viewed as part of the controversy. It is this pervasive assumption that we question in this article.

Within the traditional positivist interpretation of science, the role of researchers in relation to scientific controversies appears to raise few methodological problems. The conventional view is that social researchers should be objective in their assessment of social evidence. This usually implies that the social researcher is not directly involved in the issue being studied.

However, because positivists treat scientific knowledge as different from other sorts of belief such as religion or "public opinion," objectivity in relation to scientific knowledge appears to mean, for the social scientist, accepting received scientific facts and theories as the truth. It can be argued that because science decides which side is correct, it does not compromise the social scientist's objectivity to become involved in support of the correct side. Indeed, the social researcher may be attracted to the controversy because of requests from participants or be drawn to it by a duty to support truth against misguided opponents. Martin Gardner's (1957) popular treatment $F$ ads and Fallacies in the Name of Science illustrates well the approach also adopted in more scholarly treatments. From the point of view of those on the other side, social scientists taking part in this way are definitely "captives of controversy." From these social scientists' own point of view, 
and that of the side of scientific orthodoxy, they are simply supporting truth against falsity and are not compromised at all.

A relativist or social constructivist approach does not necessarily raise dilemmas for social researchers either, but for an entirely different reason. Within the strong program, researchers study disputes "naturalistically," and this requires their epistemological and social neutrality. Social researchers, we are told, should not grind an evaluative ax. If researchers are "captured" by either side and become part of the debate, then they are deemed to have failed to maintain a symmetrical approach. This assumption within the relativist perspective is the main focus of our article.

A leading instance of alleged "capturing" in relativist controversy analysis is the study by Collins and Pinch of the dispute over the existence of psychic phenomena. Their article, "The Construction of the Paranormal: Nothing Unscientific Is Happening," analyzes the tactics used by both parapsychologists and orthodox scientists in the course of the controversy. According to Collins and Pinch, "controversy highlights social processes with particular clarity" $(1979,238)$, and the study of the social processes involved in these attempts to legitimate parapsychology also provides insights into the maintenance of the dominant scientific culture.

From the perspective of their relativist stance, Collins and Pinch argue that the "actual existence" of the paranormal phenomena is redundant and that their position on the existence of the phenomena is neutral $(1979,262)$. However, in an added note we learn that Collins and Pinch's article has been drawn into the debate and used to support the parapsychologists' case. Parapsychologists commended the article, while critics of the field charged the authors with "selective reporting" rather than scientific inquiry (1979, 263).

Defending themselves against these charges, Collins and Pinch claim they are "professional sociologists" who are "disinterested in these questions" $(1979,263)$. This defense is not accepted by the discourse analysts Mulkay, Potter, and Yearley, who sought to undermine the relativist analysis of parapsychology by Collins and Pinch by alleging that the latter were "in a disguised fashion, constructing their analysis from the point of view of (some) parapsychologists" (Mulkay, Potter, and Yearley 1983, 187). That partisans on both sides of the controversy saw Collins and Pinch's analysis as favoring the parapsychologists' case is used by the discourse analysts to support their criticism (Mulkay, Potter, and Yearley 1983, 188). According to Mulkay, Potter, and Yearley, the reason for this lack of social neutrality is that Collins and Pinch uncritically adopted the parapsychologists' perspectives and terminology. 
This methodological demand for a separation between researcher and researched may appear to work for historical studies and for disputes contained within the scientific community. In such cases the research subjects cannot, or may not want to, deploy the social research in their struggles: historical subjects, being dead, cannot bite back, and social scientists have little perceived status in technical disputes between scientific experts. But this convenient separation between researcher and researched breaks down in current controversies that involve matters of public policy or some other strong link to the broader community. We will use our own experiences in controversy analysis to illustrate this claim. For convenience, each of the three case studies is presented in the first person singular, though each presentation has been shaped by our mutual discussions and comments.

\section{Pam Scott on the Controversy over the Importation of Live Foot-and-Mouth Disease Virus into the Australian Animal Health Laboratory}

When I began my study into the establishment of the Australian Animal Health Laboratory (AAHL), I knew almost nothing about the topic apart from a few brief newspaper reports. The establishment of the laboratory was initially thought to provide a good case study for looking at how government decisions about "big" science and technology are made in Australia.

The idea that Australia needed a laboratory to diagnose exotic animal diseases was raised in the late 1950s. Investigations into the feasibility and desirability of establishing such a facility were conducted at various stages throughout the 1960 s and 1970 s by the Commonwealth Scientific and Industrial Research Organization (CSIRO) and the Commonwealth (federal government) Departments of Health and Primary Industry. These groups lobbied very actively for support from the government. Government approval was given for the AAHL in 1974; building commenced in 1978 and was completed in $1985 .^{3}$

There was little public debate about the need to establish a laboratory for diagnosing and studying livestock diseases that, by the good fortune of geographical isolation and the good management of strict quarantine regulations, Australia had avoided. The reason for this lack of attention was that most of the planning was not made public. Most citizens, including farmers who had a particular interest in animal health, were unaware of the plans to build the laboratory and of its functions. 
It was not until 1981 that farmers' interest was captured when they learned that CSIRO had sought and received government approval to import live foot-and-mouth disease virus into the laboratory when it was completed. It should be understood that foot-and-mouth disease is especially feared by farmers. It is highly infectious, and an outbreak would result in the immediate closure of Australia's export market for meat and livestock, thereby costing the Australian economy millions of dollars and ruining many farmers.

The controversy that developed over the importation of the live virus contained a number of elements. First, there was the debate on risk: some claimed there was no risk from having the virus at AAHL, others (mainly farmers) argued that any risk was unacceptable. Structural security of the laboratory, the likelihood of human error, and the consequences of not having the live virus were all hotly debated. Then there was the debate on the need to have live virus. Proponents argued that the laboratory could not function effectively without live virus, while opponents (who included scientists) claimed live virus was not needed. CSIRO, which was to administer the laboratory and was its main advocate, unwittingly called into question the need for the laboratory itself when some of its scientists claimed that without live virus the facility would be a "white elephant" (Scott 1989).

Laboratory proponents claimed that farmers' fears were irrational and emotional and were fanned along by a few scientists who feared their research budgets would be adversely affected by AAHL's research program. Opponents pointed to "empire-building" and stubbornness as CSIRO's motivation. So the battle lines were drawn and the debate raged for several years (Scott 1988a).

I tried to keep clear of any active involvement in the debate. I had no interest, involvement, or stake in the outcome and no expertise in veterinary health matters. I intended to be dispassionate and objective in reporting my findings, and I was confident that I could maintain the necessary neutrality.

My research began with the readily available public documents on the laboratory, such as government and parliamentary reports, but then I needed to go beyond these public accounts of decision making and talk to the individuals involved. My first encounter was with an "insider" opponent who provided me with a variety of background materials and information about which documents to request from the authorities. So to some extent, I "entered" the debate via the opponents of the laboratory.

My next major encounter was with CSIRO. This is the organization responsible for administering and operating the laboratory as well as its most powerful and prestigious advocate. When I met with members of the CSIRO Executive to discuss obtaining access to CSIRO files, their attitude was 
extremely defensive and cautious. They agreed to give me access provided I cleared anything I wrote on the subject with them. This approval opened up vast quantities of material and facilitated access to the files of other government bodies.

While both sides supplied me with information, the laboratory proponents did so reluctantly, perceiving my interest as a threat to their already damaged reputation, and while appearing cooperative, they were anxious to maintain control over my work. The laboratory opponents, on the other hand, were not uniform in their views. Some saw my work as exposing the politics of CSIRO, some saw it as vindicating their opposition, others hoped it would settle the issue - but all thought it was important to reveal and record what had happened.

My detailed documentation of the decision-making process and the background to the controversy was not meant to support one side or the other, to nominate winners or losers, but to reveal the social processes shaping the knowledge claims. The disputants themselves, however, were not so sociologically enlightened. They adopted a traditional positivist stance. For them it was a conflict with a right and a wrong side, with winners and losers. And my work was incorporated into the debate.

The opponents of the laboratory were primarily farmers and their organizations, but they also included members of the public and some scientists, who were critical of what they perceived as an unnecessary, costly, and high-risk enterprise. They had been labeled by the laboratory proponents (who were primarily veterinary scientists, CSIRO, and government bureaucrats), as irrational, unscientific, emotional, biased, and politically and economically motivated in their actions. This depiction placed the opponents at a considerable disadvantage in the context of the proponents' claim to objective scientific authority. My analysis corrected this imbalance by showing the nonscientific, value-laden, and politically motivated basis for the proponents' decision making. Because this was seen as undermining the proponents, I, like Collins and Pinch, was perceived by both sides as favoring the opponents.

The opponents of the laboratory described my work as scholarly and well documented. The proponents claimed that it was a partisan presentation, that I had started from a conclusion and then sought evidence to support it, and that I wore blinkers. One of them called one of my papers a "mischievous beat-up" and made reference to "dung beetles digging in the droppings of time." When I submitted work in progress to CSIRO, it was closely scrutinized and my interpretations and conclusions were constantly challenged. 
On the other hand, the laboratory opponents requested copies of my papers, circulated them, and invited me to address farmers' groups.

One of the effects of my research was to make available information that was not widely known or had been forgotten. Many participants did not know the background to the establishment of the laboratory, and even those involved in the decision making did not always have a complete picture of events. The spreading of information and even the knowledge that someone was actively researching the controversy altered the debate. In other words, my very presence changed what I was investigating.

Was I a bad researcher who was captured by the laboratory opponents and seduced by their attention, or was this the inevitable outcome of my research?

\section{Brian Martin on the Fluoridation Controversy}

The question of whether fluoride should be added to public water supplies to reduce tooth decay has been one of the most vociferously debated issues concerning science and public policy over the past forty years. It involves scientific issues, such as the assessment of the effectiveness of fluoride in reducing tooth decay and the status of claims of health risks, such as skeletal fluorosis, allergic and intolerance reactions, and genetic effects including cancer. It also involves ethical and political issues, including the compulsion implicit in adding a chemical to the water supply to treat the individual and the question of who should make decisions about fluoridation. The issue has long been highly polarized, scientifically and politically.

One of the reasons I undertook my study was my long exposure to the issues through a colleague who is one of the prominent scientist critics of fluoridation. But, unlike the antifluoridationists, I have never been passionately concerned about whether water supplies are actually fluoridated. I regularly drank large amounts of fluoridated water before becoming acquainted with the controversy and continue to do so. My interest was and is in the politics of science as revealed through the controversy.

One of my first tasks was to study earlier sociological treatments of the fluoridation controversy. There have been many dozens of these, and almost all of them use a traditional positivist approach: fluoridation is assumed to be scientifically correct, and there is little or no discussion of the scientific evidence. Scientific evidence raised by critics of fluoridation is almost entirely unmentioned in these studies. The social scientists have seen their task as one of determining the reasons for the opposition to fluoridation. A range of hypotheses have been studied: the demographic characteristics of 
opponents have been studied (opponents were found, in some studies, to be disproportionately low in education, politically conservative, and older); the opposition has been explained by concepts such as irrationality, alienation and confusion (Martin 1989).

A number of the social researchers reveal not only their strong commitment to fluoridation but also the relation of this commitment to their studies. The United States Public Health Service, a leading force behind fluoridation since 1950, invited Aaron Spector to study the issue, and this led to the major project by Crain, Katz, and Rosenthal $(1969, v)$. These authors assume that fluoridation is "progressive" and "rational" and agonize over the political difficulty that many citizens oppose it $(1969,227-28)$.

Many social scientists studying fluoridation have seen their research as a source of insight and advice for the proponents. For example, Kegeles (1961), in a commentary on social science research on fluoridation, concluded that "While future research will undoubtedly continue to emphasize understanding rather than action, there seems reason to be optimistic that help for the [profluoridation] practitioner will be one of the eventual by-products." Gamson (1965) wrote on "How to Lose a Fluoridation Referendum," giving counsel to proponents on what they should not do.

Twenty years later, the quest for social science understanding useful to proponents continues. Hastreiter $(1983,409)$ tried to combine several different social science perspectives: "Only by using a broad spectrum of behavioral social science analyses can the complex process of fluoridation conflict be conceptualized and ameliorated." There is not a clear boundary between social science research and what can be called campaigning literature. Isman's (1981) "Fluoridation: Strategies for Success" is a good example. Isman draws on both social science studies and practical experience in drawing up recommendations for successful fluoridation campaigns.

As noted earlier, some would argue that there is no contradiction involved in partisan social research if it is assumed that one side in the controversy is supported by scientific truth. Indeed, participation in the controversy on this particular side may be considered a moral imperative. Gamson $(1961,54)$ concludes that "those who believe that truth needs no advocate need only witness a few of the more heated fluoridation controversies." Hastreiter $(1983,486)$ states that "as a lesson in sociopolitical interaction, the failure to achieve universal water fluoridation is a demonstration of humanity's tenuous ability to apply the knowledge of proved, cost-effective disease prevention to everyone's benefit." Such quotations abound in the field. ${ }^{4}$

Unlike most of these previous researchers, I undertook my study with the intention of using the tools of relativist analysis. Obtaining and studying both 
the scientific and sociological literature on fluoridation through standard sources, literature searches, and so on, presented no apparent methodological problems. It was when interacting with fluoridation partisans that the stance of symmetry became increasingly difficult.

My social interaction with partisans in the controversy began with letters to people outside Australia who had been involved in the debate. From letters to fifty-one individuals in eleven countries over several years, I received replies to thirty-six. There was not much difference between the response rates for known proponents and opponents of fluoridation. But some of the opponents were much more energetic correspondents than any of the proponents, plying me with numerous articles, names of people to contact, references, and comments. No profluoridationist did the same. This differential response was bound to affect my writing: I was aware of materials, such as personal correspondence, most of which had been supplied by antifluoridationists.

As part of my study, I interviewed eleven leading proponents and six leading opponents of fluoridation in Australia, most of whom were scientists, dentists, or doctors. Only a few of these knew of me and my work before the interviews. Most of them were forthright and helpful. But it soon became clear that my minor role in the controversy had preceded me.

Professor Elsdon Storey at the University of Melbourne told me, after an hour or so of our interview, that he knew what I was going to conclude in my study: he had seen a report of a talk of mine on suppression of dissent, in which I referred to cases of suppression of scientist opponents of fluoridation. He demanded that anything I wrote that mentioned him be shown to him in entirety before being seen by anyone else.

I subsequently received a letter from another senior academic proponent of fluoridation, Professor Jack Martin, ${ }^{5}$ also requesting that he not be quoted in any way without first approving the entire article. I inferred that he had talked to Storey after my interviews with them both. After I had prepared a draft paper called "Coherency of Viewpoints among Fluoridation Partisans" (later published as Martin 1988a), I sent copies to all interviewees for their comments. I designed the text so that I did not refer directly to the contents of the interviews with Storey and Martin, only noting the existence of the interviews and referring to a published letter by Storey. I received comments from five of the six opponents interviewed, including some quite critical ones. The only proponent responses were from Storey, who said he did not want to be associated with my article in any way, and Martin, who requested that he not be mentioned in the article, not even in the list of interviewees (a request that I declined). 
Clearly, this was a very one-sided response to my work. It was not unexpected, since my symmetrical analysis of the controversy meant that the antifluoridationists were given much more credence than is usually the case in the standard scientific or sociological literature. The effect was to isolate me from further insights into profluoridation thinking (except through the literature), while keeping channels open to antifluoridation thinking.

Later, I organized my material into a book and tried to obtain critical comments on the manuscript from both proponents and opponents. The three opponents I approached each readily provided significant comments on the draft, but obtaining comments from proponents was a more difficult task. I received comments from only four of the twelve international proponents of fluoridation I approached. These responses were invaluable: without them, it would have been far harder to obtain a good picture of the proponent case, and even easier to be drawn into the camp of the opponents.

When my articles appeared in Metascience, Social Studies of Science, and Sociological Quarterly, the fluoridation opponents circulated copies of them. The work was useful to their cause. In one case, a leading British opponent made my articles the subject of a couple of his newsletters (although to some extent for the purposes of criticism).

The fluoridation controversy is so highly polarized that any analysis that is not strongly profluoridation is seen as antifluoridation. In this context, many proponents apparently saw me as an opponent as soon as they saw the type of symmetrical analysis I was undertaking. Therefore, in one sense there was not a lot of effort required to "capture" me to the antifluoridation cause. Nevertheless, a number of antifluoridationists were quite critical of some of my statements. The most common criticism from both sides was that I had not given enough credence to the overwhelming body of science that supported their case. The trouble was that the two sides differed so completely about how the science was to be interpreted!

My experiences cannot be attributed specifically to adopting a relativist framework. Similar problems beset positivists who give less than complete support to the orthodox scientific position. Mazur's $(1973,1981)$ classic article "Disputes between Experts" analyzed the rhetoric of both proponents and opponents of fluoridation, as well as partisans in the controversy over low-level ionizing radiation. Mazur's article has been highly cited in the general social science literature, but it has seldom been mentioned by profluoridation social analysts.

Edward Groth III (1973) studied fluoridation in the early 1970s as an issue of public policy. He examined the scientific evidence and arguments on both sides in considerable detail. Groth was not interested in supporting or 
opposing fluoridation, but his intended "neutral" position was not seen this way by partisans. Opponents eagerly supplied him with information; proponents tried to discredit him personally and portray him as an antifluoridationist. Groth avoided being a "captive of controversy" only by getting out of the area (Groth 1988).

Groth did not use a relativist conceptual framework, but his adoption of a neutral, critical-of-all-claims stance served as a de facto relativism. Many of Groth's experiences were forerunners of my own. The stance of relativist symmetry seems to provide no special mechanism for avoiding de facto partisanship.

\section{Evelleen Richards on the Vitamin $\mathrm{C}$ and Cancer Controversy}

The vitamin $\mathrm{C}$ and cancer controversy centers on the attempt by Linus Pauling (Nobel laureate and well-known antiwar activist and advocate of vitamin $\mathrm{C}$ as both preventative and therapy for the common cold) and Ewan Cameron (a Scottish surgeon) to elaborate theoretically and demonstrate their claim that vitamin $\mathrm{C}$ megadose can control or palliate cancer. It is a wellpolarized controversy that has spilled over into the popular press. Pauling and Cameron apart, the interested parties include the "cancer establishment," various influential medical and scientific journals, the medical profession as a whole, nutritionists, megavitamin therapists, the holistic health movement, the health food industry, the pharmaceutical industry, and the many tens of thousands of cancer patients who, largely as a result of Pauling's and Cameron's well-publicized claims, currently take large daily doses of vitamin C. The dispute has become particularly intense over the claims and counterclaims surrounding the two negative clinical trials of vitamin C carried out by leading American oncologists at the Mayo Clinic in 1979 and $1985{ }^{6}$

The literature on medical controversies is dominated by the standard positivist assumption that even the most protracted and rancorous conflicts may be resolved by the application of the scientific method to medicine in the form of the rigorously designed and properly applied controlled clinical trial (Lasagna 1980; Doyle 1983). In the case of disputes involving alternative or marginal therapies, analysts generally have uncritically adopted the orthodox "scientific" medical position. They focus almost exclusively on the "unscientific," "irrational," or "unproven" claims of the alternatives and perceive their analytical task in terms of explaining the popular "mistaken" 
or "credulous" adherence to such scientifically unproven or unjustifiable therapies. The most partisan of these analysts are committed to the exposure of "quacks" and "charlatans," and their studies have been incorporated into the antiquackery crusades of orthodox organizations such as the American Medical Association and the American Cancer Society (for example, Young 1967, 1972; Holland 1982). ${ }^{7}$

There is little in the literature on contemporary medical disputes, particularly those involving alternative therapies, that is consistent with a relativist epistemology. The more sociologically informed analyses by Petersen and Markle (1979a, 1979b; Markle and Petersen 1980) of the laetrile controversy avoided espousing the orthodox cause. They claimed a "causal, impartial and symmetrical" approach (Petersen and Markle 1979b, 159). But their analyses still lent themselves to the standard view that the facts about disease and its treatment may be objectively determined, and that it is their interpretation from divergent social, political, and ideological frameworks that accounts for the polarized positions of the disputants and the lack of scientific resolution of the dispute. Their persistent demarcation of facts from values, their emphasis on the overtly expansionist "political" tactics of the laetrile proponents as opposed to the delimiting "scientific" tactics of their orthodox opponents, the care with which they dissociated their "equal time" treatment of both sides from any suggestion that "both sides have similar legitimacy" $(1979 \mathrm{~b}, 159)$, led to their de facto capture by orthodoxy. Petersen and Markle's accounts of the laetrile proponents became a resource for the American Cancer Society's (ACS) "Unproven Methods" list (1987), and for such a notable "quack buster" as William Jarvis in the ACS-endorsed "professional education publication," "Helping Your Patients Deal with Questionable Cancer Treatments" $(1986,8){ }^{8}$

As with Brian's analysis of the fluoridation debate, my own attempts at a neutral relativist analysis of the vitamin $C$ and cancer controversy must be interpreted in the context of the dearth of relativist accounts of contemporary disputes over medical therapies. In this context, a symmetrical analysis that does not epistemologically privilege orthodox knowledge claims, but deals evenhandedly with the claims of orthodox oncologists and marginal therapists, is flying in the face of all tradition. As I soon found, it invites the suspicion and hostility of orthodoxy and the equally problematic embraces of the unorthodox. My thorough grounding in recent sociology of scientific knowledge had not equipped me to deal with the unintended consequences of my careful application of the interpretative tools of relativist analysis.

I am a trained historian of science with a medical background. I became interested in controversy analysis primarily because I wanted a contemporary 
string to my bow. In 1981, I cast around for a topic and settled on the vitamin $\mathrm{C}$ controversy. I had read Pauling's (1970) well-known Vitamin $C$ and the Common Cold, but I was not even aware that there was a vitamin $\mathrm{C}$ and cancer controversy until I did some preliminary reading in preparation for a research grant application. I got the grant and began my study. I did not at that stage take vitamin $\mathrm{C}$, although I now do - when I remember to!

I soon narrowed my study down to the cancer debate, which I found the most sociologically interesting and manageable. I decided on a social constructivist comparison of the medical evaluations of vitamin $C$ with those of 5-fluorouracil, a conventional but contentious cytotoxic drug, and with the putative wonder drug for cancer, interferon, which was then at the height of its hype. I presented a first paper on this comparison at our annual professional conference in Melbourne. The difference between researching issues on which the dust of history has safely settled and topical disputes was brought home to me when I was contacted by a reporter for a leading Australian newspaper. He interviewed me, obtained a copy of my paper, and published an article on my research (Anonymous 1983). I was then deluged with letters from members of the public (some of whom asked my advice about their medication) and various alternative practitioners and megavitamin entrepreneurs, all of whom interpreted me as supporting a pro-vitamin $\mathrm{C}$ position. I was also invited to write an article for an Australian alternative health journal, which I declined, as I did not want to jeopardize what I considered to be my neutral position. The only orthodox professional response I received was from a Sydney academic oncologist who had not seen the newspaper article, but who had been given a copy of my paper by one of his patients. This same oncologist tried, without success, to interest some of his colleagues in my analysis and to set up a clinical trial of vitamin $C$.

I next sent copies of my paper to Linus Pauling and also to the leading oncologists at the Mayo Clinic who had carried out what was at that stage the only orthodox trial of vitamin $\mathrm{C}$ as a cancer treatment. This trial had given negative results that were disputed by Pauling and Ewan Cameron, who was collaborating with Pauling on the clinical assessment of vitamin $\mathrm{C}$ for terminal cancer patients. I had very cordial replies from both Pauling and Cameron (who was by then medical director of the Linus Pauling Institute at Palo Alto). Pauling congratulated me on my "fine" paper and offered a few criticisms of matters of detail and interpretation. He also requested that I keep him informed of its publication progress, as the Linus Pauling Institute might want to purchase some reprints for distribution. Cameron congratulated me for my "very good understanding" of the machinations of the cancer estab- 
lishment and claimed, rather disturbingly, that his interpretation so completely coincided with mine that he might have written my pape ${ }_{i}$ himself.

My Mayo Clinic correspondents were less encouraging. One of them professed to find my study "intriguing" and thought that it had broadened his "keen awareness relative to the impact of socioeconomic factors on cancer therapies." The other was Charles Moertel, nationally famous (or infamous if you prefer) for his recent demolition of laetrile as a cancer treatment as well as of vitamin C. Moertel pulled no punches in attempting to exercise his cognitive and social authority over this upstart from Australia. While he thought that the first part of my analysis was written with admirable style and considerable objectivity, he claimed that the second part of my paper (where I dealt with orthodox cancer research and treatment) had degenerated into a diatribe against the scientific conduct of medical practice and an endorsement of quacks and charlatans. According to Moertel, I had misstated and distorted facts and had quoted him out of context for the purposes of emphasizing my own personal philosophy. In other words, while he enjoyed reading my relativist analysis of the socioeconomic shaping of the case for vitamin $\mathrm{C}$, he condemned and rejected my analogous analysis of orthodox American cancer practices. Moertel claimed that my ringing defense of Linus Pauling was biased, and he demanded correction of this. He concluded by stressing that he did not authorize my quotation of any part of his letter. As I was not prepared to rewrite my paper according to his prescription, I interpreted this letter as effectively blocking my access to this leading participant in the controversy.

Up to this point I had relied on published papers and accounts for my analysis, but in 1984, as a result of my representations, Pauling and Cameron gave me access to their personal correspondence. I used part of my research grant to travel to the Linus Pauling Institute, and, for several months, with only minimal supervision, I ransacked their extensive files. These contained a wealth of source material, including not only hundreds of their letters to one another but also their correspondence with their leading professional opponents in the dispute, with editors, research and funding bodies, and their manuscripts and referees' reports. I was given an office at the institute for my personal use and unrestricted access to a photocopier. In addition, Pauling and Cameron made themselves available for a number of lengthy separate interviews on this and subsequent occasions.

By contrast, my attempts to gain access to their orthodox opponents met with only limited success. The editor of the New England Journal of Medicine, which published both negative trials of vitamin $\mathrm{C}$ but which had 
consistently refused to publish Pauling's and Cameron's papers, refused my request for an interview on the grounds that he was "too busy." The director of the National Cancer Institute (NCI), who had engaged in an extensive correspondence with Pauling over the funding of vitamin $\mathrm{C}$ research and the interpretation of the Mayo Clinic trials, was also too busy for interview. He arranged for a stand-in, who had had only limited involvement in the controversy and who gave me one hour of his time and very guarded information and opinion. My request for access to relevant NCI documents was restricted to those that I already knew of through my study of the Pauling files and could specifically request. In short, I was forced to rely primarily on the Pauling-Cameron files and on published material.

This has resulted in a systematic bias in the documentation of the controversy, although this bias is not necessarily to the advantage of the vitamin $\mathrm{C}$ advocates. Perhaps its most significant implication is that it lays open to the closest scrutiny the expressed actions, beliefs, and motivations of the supporters of vitamin $\mathrm{C}$, while leaving those of their opponents undeclared except insofar as they are willing to represent them to the other side or in published accounts of their work. The main danger of this situation is that the claims of those most closely scrutinized may be perceived to be "biased" by the revelation of the supposedly "nonscientific" factors that have fed into their assumptions, procedures, and presentation of their work, while those of their opponents remain relatively unscrutinized and, perhaps, may be presumed freer of such contaminating influences.

In spite of my best efforts to steer a prudent path through the mine field of contemporary controversy analysis, I have become an involuntary participant in the dispute. I have not been able to dissociate myself from being viewed by the vitamin $\mathrm{C}$ advocates as an ally in their just struggle. Everything I write seems to confirm them in this opinion.

In 1986 the British journal New Scientist published my account of the recently concluded and problematic second Mayo Clinic trial of vitamin C (Richards 1986). Pauling had been unable to secure publication of his criticisms of this trial in the mainstream medical or scientific literature, so my account was an important vehicle for their dissemination. In addition, my New Scientist article was picked up and summarized by the American publication Medical Self-Care, and so made available to the alternative network (Freer 1986). After this, I found it possible to secure previously inaccessible and restricted documents and letters via alternative moles at the NCI, the U.S. Office of Technology Assessment (OTA), and even the Mayo Clinic.

When I recently returned to the Pauling Institute to update my material, I found myself and my work entering into Cameron's applications for NCI 
grants and his ongoing publication negotiations with the editor of the $\mathrm{New}$ England Journal of Medicine. Pauling cites my work in his public lectures on the Mayo Clinic "fraud" and refers his correspondents to it and to me. My 1988 article in Social Studies of Science was viewed as a "scholarly" and "objective" account by Pauling and Cameron. Although they have not always agreed with my interpretation of events, I am regarded at the Linus Pauling Institute as the "official unbiased historian" of the dispute.

On the other hand, my attempts to elicit some response to my work from orthodox American oncologists and nutritionists have met with very little success. Nor, in spite of my representations of their relevance to the major forthcoming report on the evaluation of unconventional cancer treatments, was I able to interest the OTA in my published analyses of the vitamin $\mathrm{C}$ and cancer controversy. Vitamin $\mathrm{C}$ is featured in the OTA revised draft report as the unconventional treatment to have undergone the most complete orthodox testing. The detailed discussion of the Mayo Clinic trials is based on the OTA-commissioned report of Dr. Jack Yetiv, the author of a book summarizing recent scientific findings on popular nutritional practices (Yetiv 1986) and a contributing editor to Nutrition Forum, the leading popular journal devoted to the exposure of nutritional quackery. In his book, Yetiv's approach to the vitamin $\mathrm{C}$ controversy was the standard positivist one: that vitamin $\mathrm{C}$ has been tested in the two "carefully performed scientific studies" carried out by the Mayo Clinic and that "current evidence clearly suggests that vitamin C has no role in the treatment of cancer" $(1986,183-84)$. This same partisan approach is evident in the section on vitamin C in the OTA draft report, which gives no coverage to Pauling's and Cameron's criticisms of the Mayo Clinic trials or to my own work. As a result of my representations, I was invited by the OTA to review this draft. My submission opposes Yetiv's interpretation, and disputes, on sociological grounds, the lack of symmetry in the OTA draft report.

My position of neutral, symmetrical analysis has led finally to my active intervention in the dispute. I can only conclude, like Pam and Brian, that I too have been "captured."

\section{Implications}

First, sociological studies of contemporary controversies must be viewed as potential resources in social struggles over scientific or technical knowledge claims. Our experiences suggest that more often than controversy analysts care to acknowledge, the analyst becomes a participant in what 
Latour and Woolgar (1979) have very aptly described as the "fierce fight to construct reality." The analyst is at the front lines of the battle. It is so easy to be caught in the cross fire that many prefer to don positivist camouflage and seek shelter in the best-fortified trench, rather than venture out into the no-man's-land (which is even more a no-woman's-land) of sustained symmetry. The combatants have a good deal at stake in the sociologist's interpretation and presentation of news from the war zone. Their perceptions of what the analyst is up to, or rather, of what the analyst should be up to, inevitably enter into the reconstruction of the story. Both sides to a dispute have opposing and unshakable convictions as to who are the heroes and the villains involved and where truth and justice lie. If they do not welcome the analyst's attempt to deal symmetrically with the claims of their opponents, they may withdraw their cooperation or actively hinder the study. Alternatively, one side may react more sympathetically to the analysis, and attempt to win the analyst to its cause.

This leads us to our second conclusion: an epistemologically symmetrical analysis of a controversy is almost always more useful to the side with less scientific credibility or cognitive authority. In other words, epistemological symmetry often leads to social asymmetry or nonneutrality. The side with fewer scientifically or socially credentialed resources is more likely to attempt to enroll the researcher, whereas the better-credentialed side views an epistemologically symmetrical analysis as threatening to its cognitive and social authority, and it is more likely to react to the analyst with hostility or suspicion. Each case we have discussed has followed this pattern. We do not consider our experiences to be unique. Without buying into the boundary dispute between discourse analysts and Bath relativists, we think that this is precisely what happened to Collins and Pinch in their study of parapsychology. Parapsychologists, who lacked the sources of cognitive and social power available to orthodox scientists, interpreted the symmetrical analysis of Collins and Pinch as support for their cause and deployed it in their struggle against the orthodox scientists.

There is no reason to expect that discourse analysts are exempt from this process. As argued by Doran (1989), the discourse analysts are subject to the same problems of reflexivity and recursion as the strong program analysts they criticize. Discourse analysts certainly have not shown how they might avoid being captives of controversy.

Our third conclusion is that the intervention by the analyst perturbs the dispute. Among other problems, this may make it more difficult for the analyst or other researchers to obtain access to participants and documents. 
It is possible, we suggest, for the analyst's "unwitting" intervention significantly to change the course of the controversy.

So, methodological imperatives to the contrary, the controversy analyst, wittingly or not, may become a partisan participant in the debate. The view, raised to a principle in relativist approaches to controversy analysis, that social researchers must be neutral or apolitical observers requires radical reassessment. The political role of the researcher must also be addressed in any full-blooded controversy analysis. Our position is that symmetrical analysis is an illusion: the methodological claim of neutral social analysis is a myth that can be no more sustained in actual practice than can the scientist's belief in a universal and efficacious scientific method. We think that an analytic insistence on the political role of the analyst cuts through the Gordian knot of the sterile reflexivity debate.

The irony of our analysis is that the guise of neutrality is one of the best ways to be an effective partisan. The positivist controversy analyst, employing a "sociology of error," is an effective supporter of scientific orthodoxy through stigmatizing its critics; the relativist analyst, through ostensible symmetry, is an effective supporter of the critics of orthodoxy by giving them unusual credence. An active partisan who undertakes either form of analysis has less credibility than an apparently independent and neutral person. This is precisely why partisans on one side point to the analyst, as independent authority, as support for their cause, while those on the other side try to paint the analyst as not being independent.

Our analysis fits nicely into the framework of the "weak program of the sociology of scientific knowledge" as presented by Chubin and Restivo (1983). The weak program does not distinguish between the controversy and the analyst: the social scientist is automatically part of the controversy. The implication is that the analyst is more than a detached observer: the analyst should be critically involved, in the role of citizen.

Although the weak program provides a theoretical solution to the problem of the disjunction between participants and analysts of controversies, it provides no practical solution to the dilemmas posed by the prospect of being a captive of controversy. The analyst may employ a positivist analysis, a strong program analysis, a weak program analysis, or whatever. But that is simply the analyst's self-description. The (other) controversy partisans are likely to ignore motivations and methods and try to enroll, discredit, or otherwise deal with the analyst as their interests dictate. The implications of this for the study of controversies remain to be fully assessed. 


\section{Notes}

1. Some excellent surveys are Engelhardt and Caplan (1987) and Nelkin (1979).

2. Key works in relativist controversy analysis include Collins (1981, 1985), Pickering (1984), and Pinch (1986).

3. For a full account of the history of the laboratory see Scott (1986) or, for a shorter version, Scott (1988b).

4. For a more detailed discussion see Martin (forthcoming), where the relation between social science work critical of fluoridation and participation in the debate is also discussed.

5. No relation to Brian Martin.

6. For a detailed analysis of the vitamin $C$ and cancer dispute see Richards (1988, forthcoming).

7. The most notable exception to such positivist orthodox partisanship is Harris Coulter's (1973) scholarly account of the historical conflict between homeopathy and the American Medical Association. Coulter mounted a stinging attack on orthodox drug therapy and claimed that homeopathy was more "scientific" than the former.

8. In their most recent account of the laetrile controversy, Markle and Petersen (1987) are less cautious in their dissection of the role of orthodoxy in the conflict. It remains to be seen how this more critical account is viewed by orthodoxy.

\section{References}

American Cancer Society. 1987. Unproven methods of cancer management: Active statements, 1987. New York: American Cancer Society.

Anonymous. 1983. Tradition hits cures for cancer. The Age (19 January): 3.

Bloor, David. 1976. Knowledge and social imagery. London: Routledge \& Kegan Paul.

Chubin, Daryl E., and Sal Restivo. 1983. The "mooting" of science studies: Research programmes and science policy. In Science abserved: Perspectives on the social study of science, edited by Karin D. Knorr-Cetina and Michael Mulkay, 53-83. London: Sage.

Collins, H. M., ed. 1981. Knowledge and controversy: Studies of modern natural science. Social Studies of Science 11:3-158.

1985. Changing order. London: Sage.

Collins, H. M., and Trevor Pinch. 1979. The construction of the paranormal: Nothing unscientific is happening. In On the margins of science: The social construction of rejected knowledge, edited by Roy Wallis, 237-70. Keele: University of Keele.

Coulter, Harris L. 1973. Divided legacy: The conflict between homeopathy and the American Medical Association. Richmond, CA: North Atlantic Books.

Crain, Robert L., Elihu Katz, and Donald B. Rosenthal. 1969. The politics of community conflict: The fluoridation decision. New York: Bobbs-Merrill.

Doran, Chris. 1989. Jumping frames: Reflexivity and recursion in the sociology of science. Social Studies of Science 19:515-31.

Doyle, Rodger Pirnie. 1983. The medical wars: Why the doctors disagree. New York: William Morrow.

Engelhardt, H. Tristram, Jr., and Arthur L. Caplan, eds. 1987. Scientific controversies: Case studies in the resolution and closure of disputes in science and technology. Cambridge: Cambridge University Press. 
Freer, Bonnie. 1986. Vitamin C for cancer: The controversy continues. Medical Self-Care 37 (November-December): 11-12.

Gamson, William A. 1961. Public information in a fluoridation referendum. Health Education Journal 19:47-54.

-1965. Community issues and their outcome: How to lose a referendum. In Applied sociology: Opportunities and problems, edited by Alvin W. Gouldner and S. Michael Miller, 350-57. New York: Free Press.

Gardner, Martin. 1957. Fads and fallacies in the name of science. New York: Dover.

Groth, Edward, III. 1973. Two issues of science and public policy: Air pollution control in the San Francisco Bay area and fluoridation of community water supplies. Ph.D. diss., Stanford University.

-1988. Letter to Brian Martin, 22 September.

Hastreiter, Richard J. 1983. Fluoridation conflict: A history and conceptual synthesis. Journal of the American Dental Association 106:486-90.

Holland, Jimmie C. 1982. Why patients seek unproven cancer remedies: A psychological perspective, Professional Education Publications. New York: American Cancer Society. (First published $\mathrm{Ca}-\mathrm{A}$ Cancer Journal for Clinicians.)

Isman, Robert. 1981. Fluoridation: Strategies for success. American Journal of Public Health 71:717-21.

Jarvis, William. 1986. Helping your patients deal with questionable cancer treatments, Professional Education Publications. New York: American Cancer Society. (First published Ca-A Cancer Journal for Clinicians.)

Kegeles, S. Stephen. 1961. Some unanswered questions and action implications of social research in fluoridation. Journal of Social lssues 17:75-81.

Lasagna, Louis, ed. 1980. Controversies in therapeutics. Philadelphia: W. B. Saunders.

Latour, Bruno, and Stephen Woolgar. 1979. Laboratory life: The social construction of scientific facts. London: Sage.

Markle, Gerald E., and James C. Petersen, eds. 1980. Politics, science and cancer: The laetrile phenomenon. Boulder, CO: Westview.

1987. Resolution of the laetrile controversy: Past attempts and future prospects. In Scientific controversies: Case studies in the resolution and closure of disputes in science and technology, edited by H. Tristram Engelhardt, Jr., and Arthur L. Caplan, 315-32. Cambridge: Cambridge University Press.

Martin, Brian. 1988a. Coherency of viewpoints among fluoridation partisans. Metascience 6:2-19.

1988b. Analyzing the fluoridation controversy: Resources and structures. Social Studies of Science 18:331-63.

-1989. The sociology of the fluoridation controversy: A reexamination. Sociological Quarterly 30:59-76.

- Forthcoming. Scientific knowledge in controversy: The social dynamics of the fluoridation debate. Albany: State University of New York Press.

Mazur, Allan. 1973. Disputes between experts. Minerva 11:243-62.

1981. The dynamics of technical controversy. Washington, DC: Communications Press.

Mulkay, Michael, Jonathan Potter, and Steven Yearley. 1983. Why an analysis of scientific discourse is needed. In Science observed: Perspectives on the social study of science, edited by Karin D. Knorr-Cetina and Michael Mulkay, 171-203. London: Sage.

Nelkin, Dorothy, ed. 1979. Controversy: Politics of technical decision. Beverly Hills, CA: Sage. Pauling, Linus. 1970. Vitamin $C$ and the common cold. San Francisco: W. H. Freeman. 
Petersen, James C., and Gerald E. Markle. 1979a. The laetrile controversy. In Controversy: Politics of technical decision, edited Dorothy Nelkin, 159-79. Beverly Hills, CA: Sage.

-1979b. Politics and science in the laetrile controversy. Social Studies of Science 9: 139-66.

Pickering, A. R. 1984. Constructing quarks: A sociological history of particle physics. Edinburgh: Edinburgh University Press.

Pinch, T. 1986. Confronting nature: The sociology of solar-neutrino detection. Dordrecht, The Netherlands: Reidel.

Richards, Evelleen. 1986. Vitamin C suffers a dose of politics. New Scientist 109 (27 February): 46-49.

1988. The politics of therapeutic evaluation: The vitamin $\mathrm{C}$ and cancer controversy. Social Studies of Science 18:653-701.

- Forthcoming. Vitamin $C$ and cancer: Medicine or politics? London: Macmillan.

Scott, Pam. 1986. The politics of science: The establishment of the Australian Animal Health Laboratory. Ph.D. thesis, University of Wollongong.

- 1988a. Dealing with dissent: On the treatment of opposition to the Australian Animal Health Laboratory and the importation of live FMD virus. Search 19 (January/February): 6-9.

1988b. The social shaping of a laboratory: The establishment of the Australian Animal Health Laboratory. Prometheus 6 (December): 248-62.

1989. Culling technological white elephants: Lessons from the Australian Animal Health Laboratory. Science and Public Policy 16 (February): 47-51.

Yetiv, Jack Z. 1986. Popular nutritional practices: A scientific appraisal. Toledo, OH: Popular Medicine Press.

Young, James Harvey. 1967. The medical messiahs: A social history of health quackery in twentieth-century America. Princeton, NJ: Princeton University Press.

1972. The persistence of medical quackery in America. American Scientist 60: 318-26.

Pam Scott is Lecturer and Coordinator of the Information Technology and Communications Unit in the Faculty of Informatics, University of Wollongong (P.O. Box 1144, Wollongong NSW 2500, Australia). She is pursuing research on the dynamics of largescale technological projects gone astray ("technological white elephants") and on information technology, especially as applied to road transport.

Evelleen Richards is Senior Lecturer in the Department of Science and Technology Studies, University of Wollongong. Her main areas of research are the social history of evolutionary biology, gender and science, and the politics of medicine and health.

Brian Martin is Lecturer in the Department of Science and Technology Studies, University of Wollongong. He has studied the exercise of power in several scientific controversies-including nuclear winter, pesticides, nuclear power, and repetition strain injuryand also written widely on peace, environmental, and educational issues. 